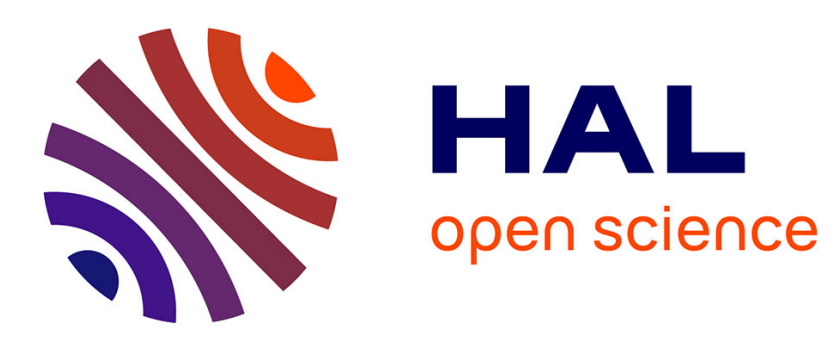

\title{
Cationic Distribution in Defect Co-Mn Ferrites from Neutron Diffraction
}

\author{
E. Elbadraoui, J. Baudour, F. Bouree, Ph. Tailhades, A. Rousset
}

\section{To cite this version:}

E. Elbadraoui, J. Baudour, F. Bouree, Ph. Tailhades, A. Rousset. Cationic Distribution in Defect Co-Mn Ferrites from Neutron Diffraction. Journal de Physique IV Proceedings, 1997, 07 (C1), pp.C1525-C1-526. 10.1051/jp4:19971214 . jpa-00254866

\section{HAL Id: jpa-00254866 https://hal.science/jpa-00254866}

Submitted on 1 Jan 1997

HAL is a multi-disciplinary open access archive for the deposit and dissemination of scientific research documents, whether they are published or not. The documents may come from teaching and research institutions in France or abroad, or from public or private research centers.
L'archive ouverte pluridisciplinaire HAL, est destinée au dépôt et à la diffusion de documents scientifiques de niveau recherche, publiés ou non, émanant des établissements d'enseignement et de recherche français ou étrangers, des laboratoires publics ou privés. 


\title{
Cationic Distribution in Defect Co-Mn Ferrites from Neutron Diffraction
}

\author{
E. Elbadraoui, J.L. Baudour, F. Bouree*, Ph. Tailhades** and A. Rousset**
}

Laboratoire Matériaux Multiphasés et Interfaces, E.A. 1357, Université de Toulon, BP. 132, 83957 La Garde cedex, France

* Laboratoire Léon Brillouin, CEN Saclay, 91191 Gif sur Yvette cedex, France

** LCMI, URA 1311 du CNRS, UPS, 118 route de Narbonne, 31062 Toulouse cedex, France

\begin{abstract}
Submicron stoichiometric cobalt manganese ferrites oxidized in air, at low temperature ( $<500^{\circ} \mathrm{C}$ ) give defect spinel ferrites which exhibit a substantial increase in coercivity, reaching a maximum for ferrites oxidized near $350^{\circ} \mathrm{C}$ and slowly cooled $\left(5^{\circ} \mathrm{C} / \mathrm{min}\right)$ from the oxidation temperature.Two ${ }^{0} 0.936^{\mathrm{Mn}} 0.355^{\mathrm{Fe}_{1.665}} \square_{0.044} \mathrm{O}_{4}$ samples oxidized at $350^{\circ} \mathrm{C}$ but exhibiting notably different coercivities because of different cooling rates ( Hc=1750 Oe after quenching ; $\mathrm{Hc}=2350 \mathrm{Oe}$ after slow cooling) have been analyzed by neutron diffraction at $\mathrm{T}=6 \mathrm{~K}$. They exhibit almost exactly the same structural and magnetic parameters, indicating that the difference between the coercivities has a purely local origin. Similar cationic distributions have been inferred Neutron diffraction reveals a classical collinear ferrimagnetism on the $A$ and $B$ sublattices of the spinel structure.
\end{abstract}

\section{INTRODUCTION}

We have used neutron diffraction at $\mathrm{T}=6 \mathrm{~K}$ for analyzing two powdered samples obtained by oxidation in air at $350^{\circ} \mathrm{C}$ of the same stoichiometric phase $\mathrm{Co}_{0.95} \mathrm{Mn}_{0.36} \mathrm{Fe}_{1.69} \mathrm{O}_{4}$ but submitted to very different oooling rates (quenching or slow cooling at $5^{\circ} \mathrm{C} / \mathrm{min}$ ) from the oxidation temperature. Thermogravimetric analysis reveals that they have the same composition $\left.\mathrm{Co}_{0.936} \mathrm{Mn}_{0.355} \mathrm{Fe}_{1.665}\right]_{0.044} \mathrm{O}_{4}$ with the same vacancy contents. However these two samples exhibit notably different coercivities because of their different cooling rates : Hc=1750 Oe for the quenched one ; Hc $=2350$ Oe for the slowly cooled one

\section{NEUTRON DIFFRACTION RESULTS}

Neutron diffraction spectra at low temperature $(T=6 \mathrm{~K}$ ) appear almost identical, whatever the sample . Refinements reveal no structural nor magnetic significant differences, within some standard deviations.The reliability factors are $\mathrm{Rp}=3.92$, $R w p=5.19$ (slowly cooled sample) and $R p=3.77, R w p=4.94$ (quenched sample)

Table 1 : Structural and magnetic parameters at $\mathrm{T}=6 \mathrm{~K}$ of $\left.\mathrm{Co}_{0.936} \mathrm{Mn}_{0.355^{\mathrm{Fe}}}{ }_{1.665^{[}}\right]_{0.044} \mathrm{O}_{4}$ (e.s.d.'s in parentheses)

\begin{tabular}{|c|c|c|c|c|c|c|c|c|}
\hline Sample & $\mathrm{a}(\AA)$ & $\begin{array}{c}\mathrm{u} \\
\text { oxygen }\end{array}$ & $\begin{array}{c}\text { Bcation } \\
\left(\AA^{2}\right)\end{array}$ & $\begin{array}{c}\text { Banion } \\
\left(\AA^{2}\right)\end{array}$ & $\begin{array}{l}<\mathrm{b}_{\text {tetra }} \\
10^{-12} \mathrm{~cm}\end{array}$ & $\begin{array}{l}<\mathrm{b}_{\mathrm{octa}} \\
10^{-12} \mathrm{~cm}\end{array}$ & $\begin{array}{l}\mathrm{M}_{\mathrm{A}}\left(\mu_{\mathrm{B}}\right) \\
\text { tetra.site }\end{array}$ & $\begin{array}{l}\mathrm{M}_{\mathrm{B}}\left(\mu_{\mathrm{B}}\right) \\
\text { octa. site }\end{array}$ \\
\hline Slowly cooled & $8.3734(2)$ & $0.3814(1)$ & $0.15(2)$ & $0.66(2)$ & $0.737(3)$ & $0.937(3)$ & $3.76(4)$ & $-3.80(4)$ \\
\hline Quenched & $8.3733(2)$ & $0.3814(1)$ & $0.15(2)$ & $0.68(2)$ & $0.727(3)$ & $0.947(3)$ & $3.74(4)$ & $-3.85(4)$ \\
\hline
\end{tabular}

\section{CATION DISTRIBUTION IN DEFECT CO-Mn FERRITES}

Admitting from the work of Chassaing et al. [1] the following structural formula :

$\mathrm{Co}_{y}^{2+} \mathrm{Fe}_{1-\mathrm{y}}^{3+}\left[\mathrm{Fe}_{0.665+\mathrm{y}}^{3+} \mathrm{Mn}_{0.287}^{3+} \mathrm{Mn}_{0.068}^{4+} \mathrm{Co}_{0.936-\mathrm{y}}^{2+}[]_{0.044}\right] \mathrm{O}_{4}^{2-}$

nentron diffraction gives cation distributions accurately from the average scattering lenghts $\left\langle b_{t e t r a}\right\rangle$ and $\left\langle b_{\text {octa }}\right\rangle$ on tetrahedral and octahedral sites (Table 1). 
$\mathrm{Co}_{0.299}^{2+} \mathrm{Fe}_{0.701}^{3+}\left[\mathrm{Fe}_{0.964}^{3+} \mathrm{Mn}_{0.287}^{3+} \mathrm{Mn}_{0.068}^{4+} \mathrm{Co}_{0.637}^{2+}[]_{0.044}\right] \mathrm{O}_{4}^{2-}$ for the slowly cooled sample $(\mathrm{y}=0,299)$. $\mathrm{Co}_{0314}^{2+} \mathrm{Fe}_{0.686}^{3+}\left[\mathrm{Fe}_{0.979}^{3+} \mathrm{Mr}_{0.287}^{3+} \mathrm{Mn}_{0.068}^{4+} \mathrm{Co}_{0.622}^{2+}[]_{0.044}^{+}\right] \mathrm{O}_{4}^{2-}$ for the quenched sample $(\mathrm{y}=0,314)$.

The average cation to anion distances $R_{\text {tetra }}=a \sqrt{3}\left(u-\frac{1}{4}\right)$ and $R_{\text {octa }}=a\left(3 u^{2}-\frac{11}{4} u+\frac{43}{64}\right)^{\frac{1}{2}}$ calculated from the cell parameter a and the oxygen positional parameter u ( Table 1 ), can also be estimated from the above cation distributions from $R_{\text {tetra }}=\sum_{i} x_{i}\left(C_{A i}-O\right)$ and $R_{o c t a}=\frac{1}{2} \sum_{i} y_{i}\left(C_{B i}-O\right), x_{i}$ and $y_{i}$ being the cation concentrations on $A$ and $B$ sites tespectively and $\mathrm{C}_{\mathrm{Ai}^{-}}-\mathrm{O}$ and $\mathrm{C}_{\mathrm{Bi}}-\mathrm{O}$ the cation to anion distances, sums of ionic radii $[2,3]$. Table 2 shows a good agreement confirming cationic distributions.

Table 2 : Average cation to anion distances calculated from a (cell parameter) and u (oxygen position) and from cationic distributions (estimated standard deviations are given in parentheses)

\begin{tabular}{|c|c|c|c|c|c|}
\hline Sample & $\begin{array}{c}\mathrm{y} \\
\text { A site }\left[\mathrm{Co}^{2+}\right]\end{array}$ & $\begin{array}{c}\mathrm{R}_{\text {tetra }}(\AA) \\
\text { neutron diffract. }\end{array}$ & $\begin{array}{c}\mathrm{R}_{\text {tetra }}(\AA) \\
\text { cation. distrib. }\end{array}$ & $\begin{array}{c}\mathrm{R}_{\text {octa }}(\AA) \\
\text { neutron diffract. }\end{array}$ & $\begin{array}{c}\mathrm{R}_{\text {octa }}(\AA) \\
\text { cation. distrib. }\end{array}$ \\
\hline Slowly cooled & $0.299(4)$ & $1.906(1)$ & $1.888(10)$ & $2.041(1)$ & $2.057(10)$ \\
\hline Quenched & $0.314(4)$ & $1.906(1)$ & $1.890(10)$ & $2.041(1)$ & $2.056(10)$ \\
\hline
\end{tabular}

\section{4-. MAGNETIC MOMENTS}

The magnetic reliability factors are Rmag=2.33 for the slowly cooled sample and $R m a g=2.80$ for the quenched sample.Neutron diffraction reveals a classical collinear ferrimagnetism with the the A-site moments opposed to the B-site moments. The sum of the A-site moments and the sum of the B-site moments supposed in a parallel alignment have been calculated from the above cation distribution formulas and from the following values for the moments assigned to the several ions $\left(\mathrm{Mn}^{3+}: 4 \mu_{\mathrm{B}} ; \mathrm{Mn}^{4+}\right.$ : $\left.3 \mu_{\mathrm{B}} ; \mathrm{Fe}^{3+}: 5 \mu_{\mathrm{B}} ; \mathrm{Co}^{2+}: 3.2 \mu_{\mathrm{B}}\right)$. These calculated values are greater than the experimental ones determined from neutron diffraction data as shown in Table 3 , which probably results from fluctuations in the alignments of the magnetic moments.

Table 3 : Calculated (from cationic distributions) and experimental (from neutron diffraction) magnetic moments.

\begin{tabular}{|c|c|c|c|c|}
\hline Sample & $\begin{array}{c}\mathrm{M}_{\mathrm{A}}\left(\mu_{\mathrm{B}}\right) \\
\text { neutron diffract. }\end{array}$ & $\begin{array}{c}\mathrm{M}_{\mathrm{A}}\left(\mu_{\mathrm{B}}\right) \\
\text { cationic distrib. }\end{array}$ & $\begin{array}{c}\mathrm{M}_{\mathrm{B}}\left(\mu_{\mathrm{B}}\right) \\
\text { neutron diffract. }\end{array}$ & $\begin{array}{c}\mathbf{M}_{\mathrm{B}}\left(\mu_{\mathrm{B}}\right) \\
\text { cationic distrib. }\end{array}$ \\
\hline Slowly cooled & $3.76(4)$ & 4.46 & $3.80(4)$ & 4.04 \\
\hline Quenched & $3.74(4)$ & 4.43 & $3.85(4)$ & 4.05 \\
\hline
\end{tabular}

\section{CONCLUSION}

This study shows that the difference between the coercivities of the two samples has a purely local origin, an anisotropic arrangement $[4,5]$ of cobalt ions being probably favoured by the multiple valence states of manganese and defects on octahedral sites, a very slow cooling allowing to create the maximum of these anisotropic configurations.

\section{References}

[1] Chassaing I., Presmanes L., Tailhades P. and Rousset A. ,Sol. State Ionics 58 (1992) 261-267.

[2] Poix P., Bull. Soc. Chim. Fr. 5 (1965) 1085-1087.

[3] Shannon R.D.and Prewitt C.T.,Acta Cryst.B25 (1969) 925-946.

[4] Néel L., J. Phys. Rad. 15 (1954) 225-239.

[5] Chikazumi S.,"Physics of magnetism", Ed J. Wiley Sons (1964) Chap 17. 